\title{
Editorial zum 80. Geburtstag von Prof. Riehm
}

T. Klingebiel, M. Schrappe

Bibliografie

DOI http://dx.doi.org/

$10.1055 / \mathrm{s}-0033-1337954$

Klin Padiatr 2013; 225

(Suppl. 1): S2

(c) Georg Thieme Verlag KG

Stuttgart · New York

ISSN 0300-8630

Korrespondenzadresse

Prof. Dr. med. Thomas

Klingebiel

Klinik für Kinder- und Jugend-

medizin

Klinikum der Johann Wolfgang

Goethe-Universität

Theodor-Stern-Kai 7

60590 Frankfurt

Thomas.klingebiel@kgu.de
Liebe Leserinnen und Leser,

wir legen Ihnen einen Sonderband der Klinischen Pädiatrie vor, den wir Prof. Riehm zum 80. Geburtstag gewidmet haben.

Der Beitrag von Prof. Riehm zur pädiatrischen Onkologie im Allgemeinen und zur Behandlung von Kindern mit Leukämien und malignen Lymphomen ist so fundamental, dass wir ihn zu seinem 80. Geburtstag in konzentrierter Form darstellen wollten. Es war uns wichtig, die Ideen und Gedanken lebendig werden zu lassen, mit denen Prof. Riehm vor mehr als 40 Jahren die Grundlagen für eine moderne pädiatrische Onkologie gelegt hat. Vor nicht allzu langer Zeit ist das Buch „Der König aller Krankheiten - Krebs eine Biografie ${ }^{1}$ von Siddhartha Mukherjee erschienen, das sehr plastisch und anschaulich die Entwicklung von Diagnostik und Therapie von Krebskrankheiten darstellt, jedoch den Beitrag von Prof. Riehm völlig ignoriert. Umso wichtiger erschienen es uns auch, wichtige Mitarbeiter und Mitstreiter im In- und Ausland, wie Prof. Helmut Gadner, Prof. Paul Gaynon, Prof. Karl Welte, Prof. Günter Henze, Prof. Alfred Reiter, Prof. Dietrich Niethammer und Prof. Fritz Lampert selbst zu Wort kommen zu lassen. Es erschien uns auch wichtig, in einer biographischen Darstellung Prof. Riehms Gedanken und Überlegungen authentisch zu dokumentieren.

Der vorliegende Band zeigt die Entstehung und das, was aus den Gedanken geworden ist. Er eignet sich dazu, die Ideen nachzuvollziehen, ihre fundamentale Bedeutung zu verstehen, aber er eignet sich auch dazu, ihn als Dokumentation des State-of-the-Art von Diagnostik und Behandlung von akuten Leukämien und Lymphomen zu lesen.

In einem Leukemia Sonderheft im Jahr $2010^{2}$ heißt es treffend: "Because the treatment advan- ces he developed were not always readily accepted by other groups working in the field, Dr Riehm spent a great deal of time and energy promoting the concept of 'BFM'-type therapy around the world. To say that he was successful in this endeavor would be a major understatement. Today, BFM-type therapy is used in the United States, Canada, Europe, South America, Australia, New Zealand, the Middle East and Asia. Under the guidance and tutelage of Dr Riehm, an International BFM study group (I-BFM-SG) has been formed, with participation of a large number of countries, some with limited resources. An intercontinental consortium from the I-BFM-SG (called ALL-IC BFM) recently completed their first major clinical trial in a large group of countries from Latin America, East Europe and Asia, with results matching those attained by other major study groups. In fact, BFM type of therapy has also recently been adopted by various adult ALL study groups, resulting in significant improvement in cure rates. It is clear that Dr Riehm is one of the most influential oncologists in the modern era. He deserves special recognition for his pioneering and prodigious accomplishments, and we appreciate his ongoing friendship and support."

Wir gratulieren Prof. Riehm zu seinem Geburtstag und zu einer Lebensleistung, die das Leben tausender Kinder und Jugendlicher hat erhalten helfen. Wir danken allen Wissenschaftlern, Ärzten, Schwestern und technischen Mitarbeitern, die diesen großartigen Erfolg mit ermöglicht haben. 